$\xi^{2}=-1$

\title{
Petrology of peridotite host basaltic lavas of northern Ngaoundéré (Adamawa plateau, Cameroon, Central Africa)
}

\author{
Njankouo Ndassa Zénab Nouraan ${ }^{1}$, Nkouandou Oumarou Faarouk ${ }^{1}$, Bardintzeff Jacques-Marie ${ }^{2}$ *, \\ Ganwa Alexandre Alembert ${ }^{1}$, Fagny Mefire Aminatou ${ }^{1}$, Tizi Arnaud ${ }^{3}$ \\ ${ }^{1}$ Faculty of Science, University of Ngaoundéré, P.O. Box. 454, Ngaoundéré, Cameroon \\ ${ }^{2}$ Univ Paris-Sud, Sciences de la Terre, Volcanology, UMR CNRS 8148 GEOPS, bât. 504, \\ Université Paris-Saclay, F-91405 Orsay, France \\ *Corresponding author E-mail: jacques-marie.bardintzeff@u-psud.fr
}

\begin{abstract}
Small volcanoes and flows of Cainozoic basaltic lavas, containing numerous mantle peridotite xenoliths, outcrop at northern Ngaoundéré in Adamawa plateau. They are composed of arena of decimeter to meter in size of bowls and blocs of dark matrix, showing crystals of olivine, clinopyroxene and oxides. All lavas present microlitic porphyritic texture with euhedral to subhedral crystals of the same phases drowned in the matrix of the same minerals plus plagioclase microlites.

Microprobe analyses show that olivine phenocrysts are relatively Fo-rich (80.9-84.3\%) compared to microphenocrysts and microcrysts (Fo71.1-75.9\%). Olivine xenocrysts are highly magnesian (83.9-89.8\%). Clinopyroxene are diopside and augite. Oxides crystals are Timagnetite and plagioclase are labradorite and bytownite.

ICP-AES and ICP-MS whole rocks analyses show that the host peridotite basaltic lavas of northern Ngaoundéré are undersaturated basanites of typical alkaline lava series. They seem not contaminated by crustal materials. They are the results of low partial melting rate of the garnet mantle source located at more than $80 \mathrm{~km}$ depth. The eruptions of northern Ngaoundéré lavas have been facilitated by Pan African cracks and they have sampled the subcontinental lithospheric mantle as xenoliths at different pressures and depths on their way to the surface.
\end{abstract}

Keywords: Adamawa plateau; Basanite; Cameroon; Peridotite; Xenolith.

\section{Introduction}

Northern Ngaoundéré area belongs to Adamawa plateau (AP), an asymmetrical horst of central Africa (Fig. 1A) bounded north and south (Fig. 1B) by pan African N70 strike-slip faults (Moreau et al. 1987). Those faults extend from Cameroon to Soudan on about $2000 \mathrm{~km}$ (Cornacchia \& Dars 1983) and crosscut the Adamawa basement and upper mantle down to depths greater than $190 \mathrm{~km}$ (Dorbath et al. 1986, Poudjom Djomani et al. 1992, Nnange et al. 2000). Adamawa faults have served as pathway for ascending basaltic magmas to reach the surface (Moreau et al. 1987, Guiraud \& Maurin 1992). Those lavas have sampled numerous fragments of sub-continental mantle xenoliths on their way. Three volcanic units are broadly distinguished in the Adamawa region (Nono et al. 1994, Temdjim et al. 2004, Nkouandou et al. 2008): The (1) Cretaceous-Paleogene lower black series mostly consists in basaltic lava flows completely transformed to lateritic soils; The (2) white intermediate series of Miocene age consists in numerous trachytes and phonolites plugs mostly North and East of Ngaoundéré and the (3) upper black series consisting of Pliocene-Quaternary basaltic strombolian cones and their associated lava flows mostly South of Ngaoundéré. The third Pliocene-Quaternary lava series is composed of three sequences lava flows (Nono et al. 1994) distinguished by their stratigraphic and surface-weathering characteristics as Upper Flow Unit (UFU), Middle Flow Unit (MFU) and Lower Flow Unit (LFU). Previous studies on the volcanic series of Ngaoundéré area (Nkouandou et al. 2008 and 2010, Fagny et al. 2012, Tiabou et al. 2015) have constrained the main petrogenesis processes at the origin of Adamawa plateau volcanism of Pliocene LFU and MFU lava series. In the Northern Ngaoundéré, basaltic lava flows (UFU) of upper black lava series have been emitted by numerous centres now observed as necks (Ngao Mokon, Ngao Kobi and Do Guessa in Mazélé area). Most of the lavas flowed radially around the centres. Only the UFU of upper black lava series contain numerous fragments of sub-continental mantle xenoliths.

This work presents the petrogenetic features of Pliocene-Quaternary volcanism from the Northern Ngaoundéré upper lava flow unit (UFU) of upper black lava series. 


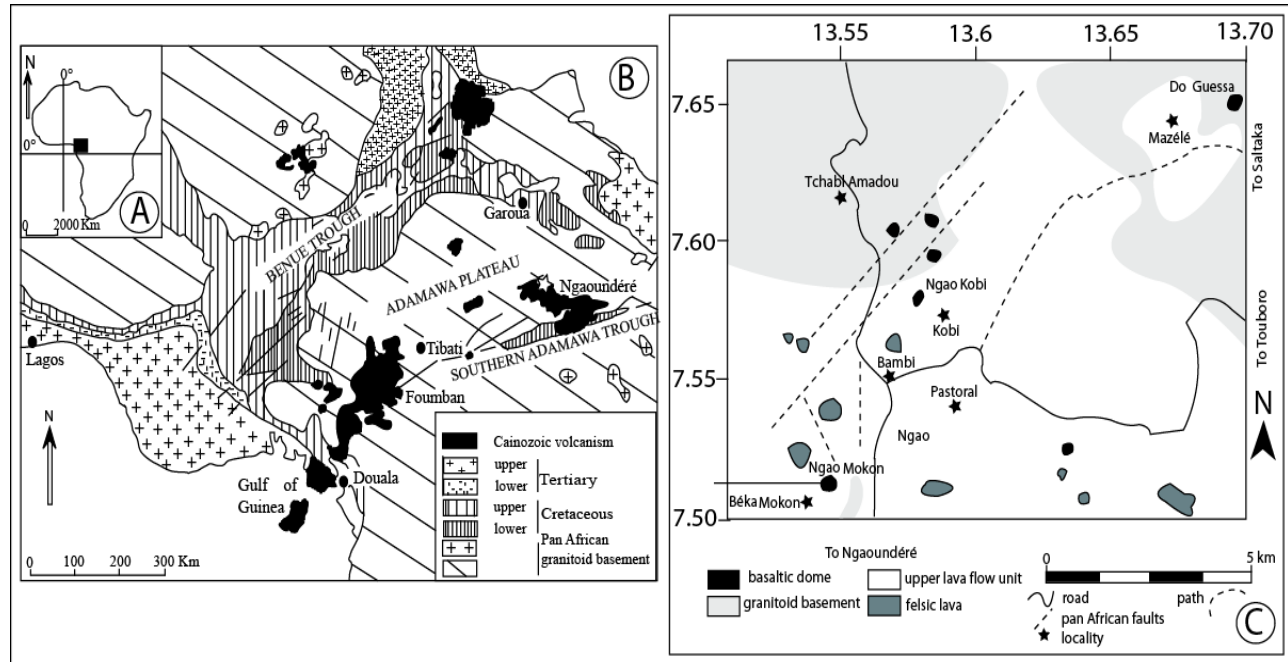

Fig. 1: Geological Sketch Map of Northern Ngaoundéré Region A: Location of Adamawa In Central Africa, B: Adamawa Plateau Location Relative to Benue Trough and C: Sketch Map of Studied Area. Fig. 1A and 1B Modified from Dumont (1987) and 1C Modified from Njankouo Ndassa (2019, Unpublished Data).

\section{Geological setting}

Adamawa plateau is an uplifted horst in central Cameroon (Fig. 1A and B) divided roughly into three blocks by two sub vertical boundaries striking ENE and traversing both the crust and upper mantle down to depths greater than $190 \mathrm{~km}$ (Dorbath et al. 1986). It results from the interaction of a regional anomalous upper mantle associated with the West African Rift System and the Central African Shear Zone (Dorbath et al. 1986). Adamawa basement limited north by Benue trough and south by Southern Adamawa trough (Fig. 1B) is hashed by numerous pan African strike-slip faults which have facilitated the ascending volcanic lavas at Cainozoic times to the surface (Moreau et al. 1987). Northern Ngaoundéré basement is composed of calco-alkaline granitoids of pan African age (500-600 Ma) displaying negative $\mathrm{Nb}$ and $\mathrm{Ta}$ anomalies (Tchameni et al. 2006, Nkouandou et al. 2008). Adamawa volcanism is composed of basaltic and felsic lavas (Nkouandou et al. 2008 and 2010) belonging to Na-under saturated suites (Temdjim et al. 2004, Nkouandou et al. 2008). There is a gap between basaltic and felsic lavas (Nkouandou et al. 2008). Felsic lavas may have been generated by differentiation by fractional crystallization of basaltic lavas coupled to minor magma mixing process and selective crustal contamination (Nkouandou al. 2008). Silica-saturated lavas of crustal origin have recently been described in Adamawa plateau in Saltaka region (Nkouandou et al. 2016).

\section{Analytic method}

Petrographic studies have been carried out on about ten thin sections prepared from the representative samples of ultramafic xenoliths host lavas at the laboratory GEOPS of the University of Paris-Sud Orsay, France. Microprobe mineral analyses of peridotite host basaltic lavas were performed on Camebax SX100 at the service Camparis of the University of Pierre et Marie Curie, Paris 6, France. The operating conditions were an accelerating voltage and a beam current as follow: olivine and clinopyroxene: $15 \mathrm{kV}$ and $40 \mathrm{nA}, 20 \mathrm{~s}$ except Si for olivine $(10 \mathrm{~s})$ and Ti for clinopyroxene $(30 \mathrm{~s})$; plagioclase: $15 \mathrm{kV}, 10 \mathrm{nA}, 10 \mathrm{~s}$; titanomagnetite: $15 \mathrm{kV}$ and $40 \mathrm{nA}, \mathrm{Si}, \mathrm{Ca}, \mathrm{Ni}: 10 \mathrm{~s}$; Mn: $25 \mathrm{~s}$; Cr; $15 \mathrm{~s}$; Al: $30 \mathrm{~s}$; Ti. Fe; Mg: $40 \mathrm{~s}$. Standard used were a combination of natural and synthetic minerals. Data corrections were made using the PAP correction of Pouchou \& Pichoir (1991).

Whole rock major and trace element analyses of host lavas peridotite were determined on representative samples by ICP-AES and ICPMS at the Acmel laboratory of Vancouver, Canada and supplement analyses at the 'Centre de Recherches Pétrographiques et Géochimiques', CRPG, Nancy, France. The prepared sample is mixed with $\mathrm{LiBO}_{2} / \mathrm{Li}_{2} \mathrm{~B}_{4} \mathrm{O}$ flux. Crucibles are fused in a furnace. The cooled bead is dissolved in ACS-grade nitric acid and analyzed by ICP and/or ICP-MS. Loss on Ignition (LOI) is determined by igniting a sample split then measuring the weight loss. The method used is that of Carignan et al. (2001) for trace elements. CIPW norm calculations have been done assuming $\mathrm{Fe}_{2} \mathrm{O}_{3} / \mathrm{FeO}$ ratio of 0.15 .

\section{Results}

\subsection{Field work and petrography}

Volcanic lavas of northern Ngaoundéré outcrop as lava flows and dome shape structures. Basaltic lava flows of studied area extend on more than $2 \mathrm{~km}^{2}$ from Béka Mokon to Mazélé locality (Fig. 1C). They are considered as Pliocene-Quaternary Upper Lava Flows (ULF) relative to the sequential volcanic eruptions which have occurred in the area (Fig. 2A). The main characteristic of northern Ngaoundéré basaltic lavas is the occurrence of numerous fragments of mantle peridotite (Nkouandou \& Temdjim 2011, Nkouandou et al. 2015, Njombie et al. 2018). Lava flows and small volcano massifs are composed of dark blocks and bowls of basaltic lavas, decimeters to meter in size $(20 \mathrm{~cm}$ to $1.5 \mathrm{~m})$. Many vacuoles, 7 to $20 \mathrm{~cm}$ wide, observed on those lavas may have been occupied by mantle peridotite xenoliths now completely altered. Slim dark brown patina covers the matrix of dark color containing blue yellowish 2 to $5 \mathrm{~mm}$ olivine crystals (10 to $15 \mathrm{vol} \%$ ), dark crystals of pyroxene ( 2 to $3 \mathrm{~mm}$ and 5 to $10 \mathrm{vol} \%$ ) and abundant fine sparkling microlites of plagioclase (1 $\mathrm{mm}$ and $30 \mathrm{vol} \%)$. Numerous fragments of yellow blackish peridotite of 5 to $15 \mathrm{~cm}$ in size are found in almost all basaltic outcrops. Peridotite fragments are rounded or sub-angular to angular shape (Fig. 2B and 2C). They are respectively composed of abundant (60 to $80 \mathrm{vol} \%$ ) of 3 to $6 \mathrm{~mm}$ in size crystals of yellow greenish olivine crystals. Pyroxene, spinel or amphibole are suspected. 

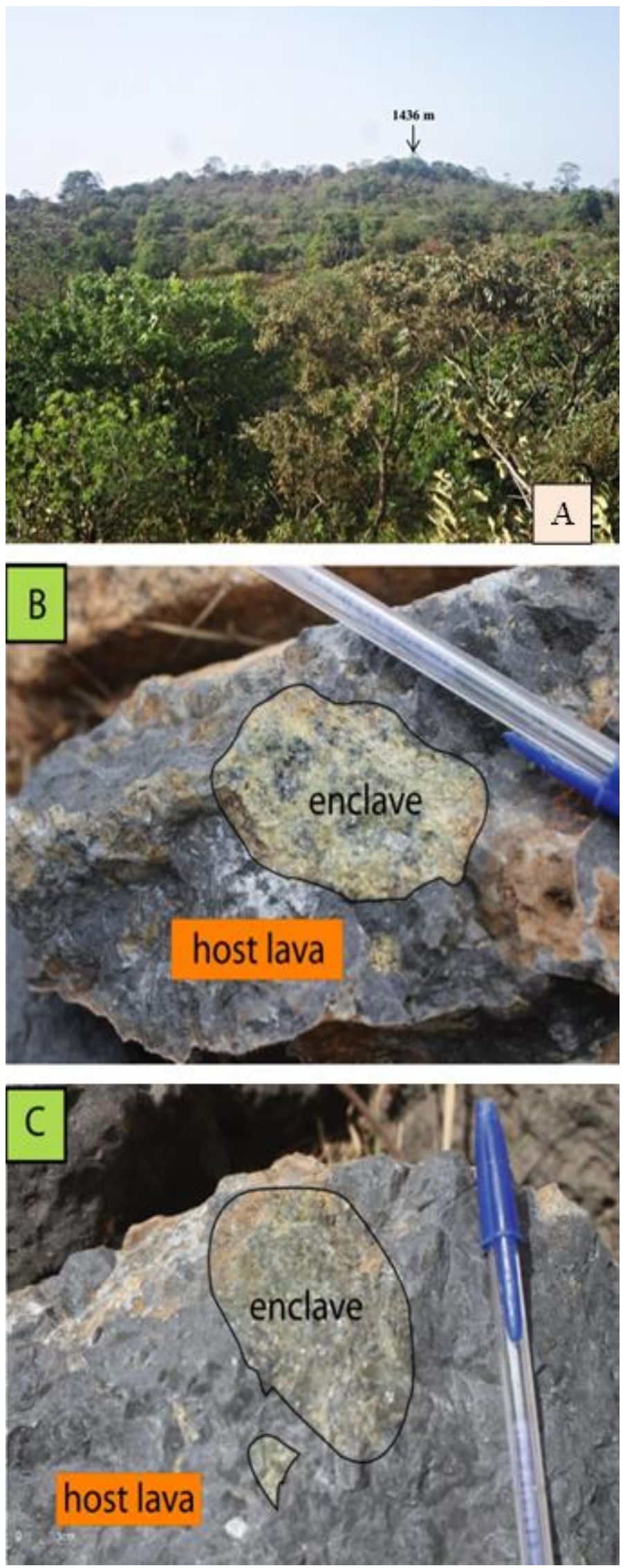

Fig. 2: A) View of Hillside of Do Guessa Volcano Exhibiting the Flow Dome Shape Form, B): Yellow Greenish Peridotite Enclave in Lava of Do Guessa Volcano and C): Egg-Shaped Peridotite Enclaves in Host Dark Lava. The Pen Is $14 \mathrm{Cm}$ Long for Scale.

Small volcanic massifs of the studied area (Fig. 1C) are Do Guessa in Mazélé (N7.651539 and E13.694999 ), Ngao Kobi in Kobi $\left(\mathrm{N} 7.585833^{\circ}\right.$ and E13.582222 ${ }^{\circ}$ ) and Ngao Mokon in Béka Mokon (N7.521649 ${ }^{\circ}$ and E13.543954 ${ }^{\circ}$ ) localities. Northern Ngaoundéré volcanoes are aligned, following N130E and N30E pan African faults. They are fragmented and they exhibit parallelepiped shape of $350 \mathrm{~m} \times 260 \mathrm{~m} \times 17 \mathrm{~m}$ to $150 \mathrm{~m} \times 80 \times 20 \mathrm{~m}$. These volcanoes are composed of angular blocks and bowls of 20 to $50 \mathrm{~cm}$, which exhibit the same petrographic characteristics as those of basaltic lava flows of the same area. Peridotite fragments ( 7 to $10 \mathrm{~cm}$ ) are omnipresent in blackish matrix of host basaltic lavas (Fig. 2B and 2C). 
On plate polarized light (Fig. 3A, 3B and 3C), all samples show microlitic porphyritic textures. They are composed of phenocrysts of olivine, clinopyroxene and oxides. Microlites and microcrysts in the matrix are the same mineral phases plus plagioclase microlites.

Two types of olivine crystals are distinguished: (1) euhedral and subeuhedral phenocrysts $(10 \%$ in volume of lava and $0.3 \times 0.5 \mathrm{~mm}$ to $3 \times 4 \mathrm{~mm}$ ) showing squat aspect and rare oxides inclusion in cores and rims (Fig. 3B). The second type crystals (2) are probably olivine xenocrysts stood out from xenoliths (less than 5 vol \% and $0.7 \times 1.2$ to $1.1 \times 2 \mathrm{~mm}$ ). They are strongly cracked, serpentinized and without oxides inclusions (Fig. 3A. 3B and 3C). Microphenocrysts and microcrysts of olivine crystals of euhedral, subeuhedral and sometimes xenomorph shape are relatively abundant ( 7 to $15 \%$ in volume, 0.1 to $0.3 \mathrm{~mm}$ ). Microcrysts of olivine are frequently associated to those of oxides in the matrix. Oxides phenocrysts (5-10\% in volume and $0.1 \times 0.3 \mathrm{~mm}$ to $0.5 \mathrm{x} 0.7 \mathrm{~mm}$ ) are subeuhedral to xenomorph (Fig. 3C) and show rounded shapes. Oxides microcrysts $(12 \%$ in volume and $0.1 \times 0.2$ to $0.2 \times 0.3 \mathrm{~mm})$ are square, rectangular or triangular in shape. Some are included or stuck in rim of olivine phenocrysts (Fig. 3A, 3B and 3C).

Clinopyroxene ( 3 to $5 \%$ in volume, $1.1 \times 1.8$ to $1.3 \times 2.2 \mathrm{~mm}$ ) phenocrysts are euhedral (Fig. 3D). They contain oxides microcrysts and sometimes show skeletal shape. Clinopyroxene microlites (less than 5 volume $\%, 0.2 \mathrm{~mm} \mathrm{long}$ ) are needle shape and intimately associated with oxides microcrysts.

Plagioclases are present exclusively as microlites (about $25 \%$ in volume, $0.1 \mathrm{~mm}$ long) acicular in shape, scattered in the matrix; they have frequently grown with oxides microcrysts (Fig. 3A, 3B, 3C and 3D).
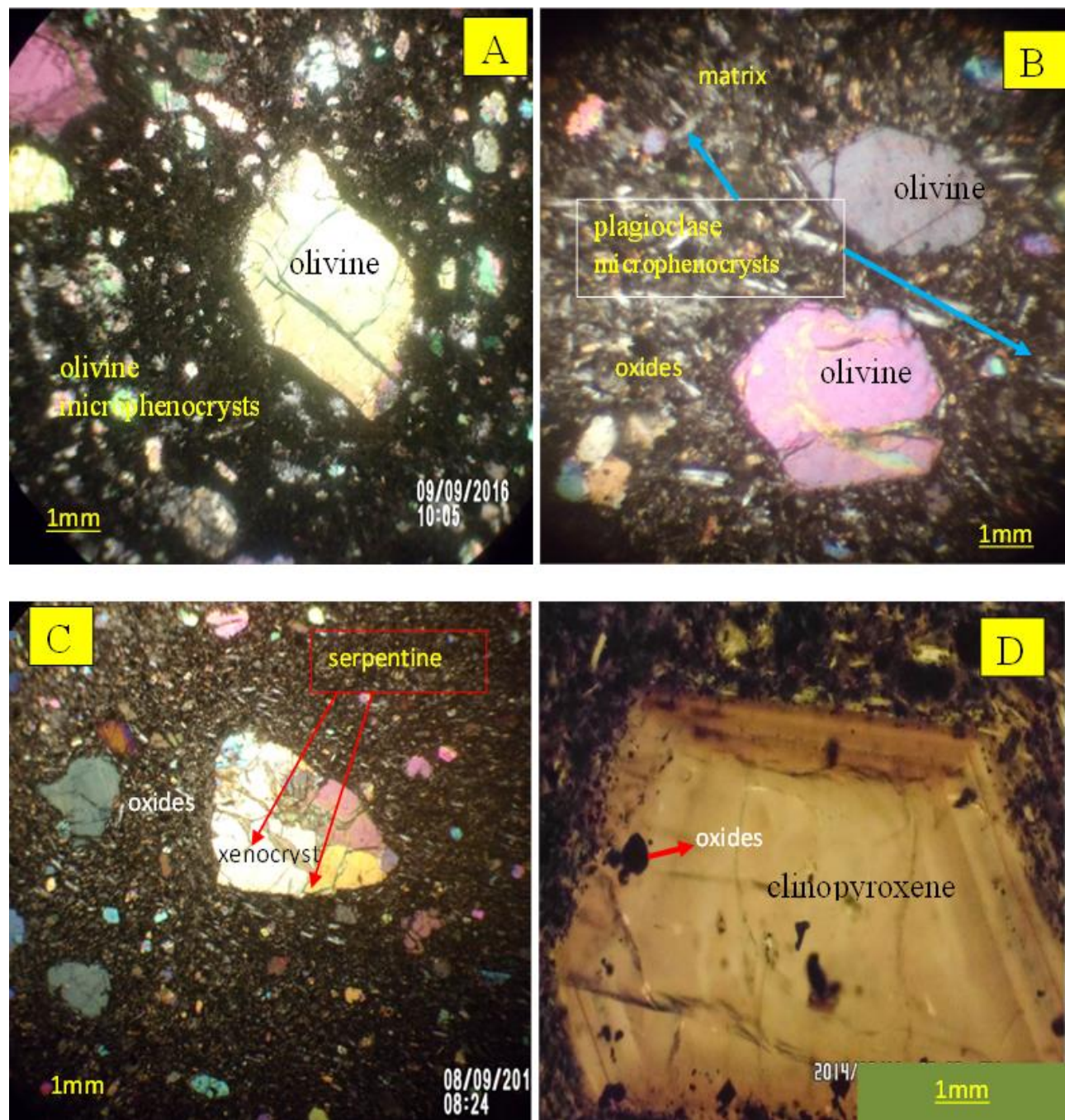

Fig. 3: A \& B: Euhedral Olivine Crystals, C: Olivine Xenocryst and D: Euhedral Zoned Clinopyroxene Phenocryst Containing Small Oxides Microcrysts.

\subsection{Mineralogy}

Microprobe chemical analyses of olivine of host peridotite basaltic lavas of northern Ngaoundéré are shown in Table 1. Olivine phenocrysts have relatively high Fo (80.9-84.3\%), $\mathrm{CaO}(0.11-0.75 \mathrm{wt} \%)$ and low $\mathrm{NiO}(0.06-0.26 \mathrm{wt} \%)$. Olivine microphenocrysts and microcrysts are less magnesian (Fo71.1-75.9 \%) with lowest Fo found in microcrysts. Reversely, olivine xenocrysts have very high Fo $(83.9-89.8 \%)$ and $\mathrm{NiO}(0.23-0.37 \mathrm{wt} \%)$ for low $\mathrm{CaO}$ contents $(0.09 \mathrm{wt} \%)$.

Phenocrysts and microlites of clinopyroxene (Table 2 and Fig. 4) are essentially diopside (Wo47.00-48.40 En-41.50-47.10 Fs5.34-10.08) in compositions (classification after Morimoto et al. 1988). They have rather high $\mathrm{TiO}_{2}(2.7-4.8 \mathrm{wt} \%)$ and $\mathrm{Al}_{2} \mathrm{O}_{3}(5.3-9.3$ wt $\%)$ contents for rather low $\mathrm{Na}_{2} \mathrm{O}$ content (0.6-0.8 wt \%). $\mathrm{Mg} \#$ are up to 87.8. One analysis is very peculiar (Table 2): this seems an augite (Wo43.20 En42.56$\left.\mathrm{Fs}_{14.23}\right), \mathrm{Al}_{2} \mathrm{O}_{3}\left(12.39\right.$ wt \%) and $\mathrm{Na}_{2} \mathrm{O}(1.6 \mathrm{wt} \%)$ rich. 
Table 1: Microprobe Analyses and Structural Formulae of Olivine Crystals of Host Peridotites Basaltic Lavas. Ph $=$ Phenocryst, Mph $=$ Microphenocryst, Mic $=$ Microcryst and Xeno $=$ Xenocryst

\begin{tabular}{|c|c|c|c|c|c|c|c|c|c|c|c|c|c|c|}
\hline ava & asanite & & & & & & & & & & & & & \\
\hline sample & LNJ13 & & & LNJ12 & & & LNZ8 & & & & LTZ13 & & LNJ115 & \\
\hline type & ph & ph & ph & ph & ph & $\mathrm{mph}$ & $\mathrm{mph}$ & $\mathrm{mph}$ & $\mathrm{mph}$ & $\mathrm{mph}$ & mic & mic & xeno & xeno \\
\hline $\mathrm{SiO}_{2}$ (wt \%) & 39.04 & 38.03 & 38.33 & 39.26 & 39.06 & 39.51 & 39.97 & 38.24 & 37.62 & 37.94 & 38.26 & 37.68 & 39.23 & 40.35 \\
\hline $\mathrm{FeO}$ & 14.92 & 17.91 & 17.16 & 14.83 & 15.65 & 21.03 & 21.41 & 22.12 & 23.73 & 22.40 & 25.09 & 23.41 & 15.01 & 9.79 \\
\hline $\mathrm{MnO}$ & 0.23 & 0.27 & 0.30 & 0.28 & 0.30 & 0.44 & 0.43 & 0.51 & 0.46 & 0.56 & 0.56 & 0.49 & 0.27 & 0.08 \\
\hline $\mathrm{MgO}$ & 44.70 & 42.42 & 43.30 & 44.67 & 43.85 & 37.90 & 36.47 & 38.43 & 37.67 & 38.42 & 35.44 & 37.89 & 44.52 & 48.46 \\
\hline $\mathrm{CaO}$ & 0.11 & 0.22 & 0.22 & 0.20 & 0.24 & 0.76 & 0.61 & 0.30 & 0.37 & 0.24 & 0.55 & 0.36 & 0.09 & 0.09 \\
\hline $\mathrm{NiO}$ & 0.26 & 0.21 & 0.22 & 0.24 & 0.22 & 0.16 & 0.14 & 0.11 & 0.21 & 0.16 & 0.06 & 0.15 & 0.23 & 0.37 \\
\hline sum & 99.26 & 99.05 & 99.53 & 99.49 & 99.32 & 99.80 & 99.04 & 99.71 & 100.06 & 99.72 & 99.95 & 99.98 & 99.35 & 99.15 \\
\hline
\end{tabular}

$\begin{array}{lllllllllllllll}\text { Si (apfu) } & 0.989 & 0.982 & 0.980 & 0.992 & 0.992 & 1.010 & 1.035 & 0.986 & 0.989 & 0.992 & 1.010 & 0.989 & 0.993 & 0.994 \\ \mathrm{Fe} 2+ & 0.316 & 0.387 & 0.367 & 0.313 & 0.333 & 0.461 & 0.471 & 0.490 & 0.521 & 0.490 & 0.554 & 0.514 & 0.318 & 0.203 \\ \mathrm{Mn} & 0.000 & 0.000 & 0.000 & 0.000 & 0.007 & 0.010 & 0.010 & 0.011 & 0.010 & 0.000 & 0.012 & 0.011 & 0.006 & 0.000 \\ \mathrm{Mg} & 1.688 & 1.633 & 1.651 & 1.682 & 1.661 & 1.483 & 1.429 & 1.516 & 1.476 & 1.498 & 1.395 & 1.483 & 1.680 & 1.793 \\ \mathrm{Ca} & 0.003 & 0.006 & 0.006 & 0.005 & 0.006 & 0.021 & 0.017 & 0.008 & 0.011 & 0.007 & 0.016 & 0.010 & 0.003 & 0.002 \\ \mathrm{Ni} & 0.005 & 0.004 & 0.005 & 0.005 & 0.004 & 0.003 & 0.003 & 0.002 & 0.005 & 0.003 & 0.001 & 0.003 & 0.005 & 0.007\end{array}$

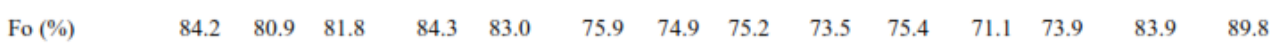

Table 2: Microprobe Analyses and Structural Formulae of Clinopyroxene Crystals of Host Peridotites Basaltic Lavas

\begin{tabular}{|c|c|c|c|c|c|c|c|c|}
\hline $\begin{array}{l}\text { lava } \\
\text { sample }\end{array}$ & $\begin{array}{l}\text { basanite } \\
\text { LMB } 110\end{array}$ & & LNZ-G1 & LMZ11 & & LNZ-B1 & LTZ13 & \\
\hline $\mathrm{SiO}_{2}($ wt $\%)$ & 44.70 & 47.22 & 44.21 & 45.95 & 44.91 & 42.43 & 47.53 & 48.83 \\
\hline $\mathrm{TiO}_{2}$ & 3.94 & 2.80 & 4.48 & 3.40 & 3.65 & 4.80 & 2.70 & 3.10 \\
\hline $\mathrm{Al}_{2} \mathrm{O}_{3}$ & 8.07 & 5.26 & 8.62 & 7.00 & 7.67 & 9.25 & 7.28 & 12.39 \\
\hline $\mathrm{Cr}_{2} \mathrm{O}_{3}$ & 0.02 & 0.03 & 0.04 & 0.04 & 0.00 & 0.00 & 0.00 & 0.00 \\
\hline $\mathrm{FeOt}$ & 7.40 & 7.16 & 7.25 & 6.69 & 7.36 & 7.60 & 6.46 & 5.58 \\
\hline $\mathrm{MnO}$ & 0.13 & 0.17 & 0.15 & 0.11 & 0.11 & 0.17 & 0.07 & 0.04 \\
\hline $\mathrm{MgO}$ & 11.73 & 13.27 & 11.43 & 12.66 & 12.04 & 10.94 & 11.74 & 9.36 \\
\hline $\mathrm{Na}_{2} \mathrm{O}$ & 0.59 & 0.61 & 0.65 & 0.62 & 0.69 & 0.74 & 0.84 & 1.60 \\
\hline sum & 99.02 & 99.17 & 99.34 & 99.01 & 98.93 & 98.15 & 99.49 & 99.64 \\
\hline Si (apfu) & 1.684 & 1.766 & 1.662 & 1.722 & 1.689 & 1.617 & 1.773 & 1.816 \\
\hline $\mathrm{Ti}$ & 0.112 & 0.079 & 0.127 & 0.096 & 0.103 & 0.138 & 0.076 & 0.087 \\
\hline $\mathrm{Al}$ & 0.358 & 0.232 & 0.382 & 0.309 & 0.340 & 0.415 & 0.320 & 0.543 \\
\hline $\mathrm{Cr}$ & 0.001 & 0.001 & 0.001 & 0.001 & 0.000 & 0.000 & 0.000 & 0.000 \\
\hline $\mathrm{Fe}$ & 0.141 & 0.103 & 0.142 & 0.111 & 0.107 & 0.111 & 0.200 & 0.170 \\
\hline $\mathrm{Mg}$ & 0.659 & 0.740 & 0.641 & 0.708 & 0.675 & 0.622 & 0.653 & 0.519 \\
\hline $\mathrm{Ca}$ & 0.906 & 0.908 & 0.907 & 0.906 & 0.907 & 0.907 & 0.914 & 0.742 \\
\hline $\mathrm{Na}$ & 0.043 & 0.044 & 0.047 & 0.045 & 0.050 & 0.055 & 0.061 & 0.115 \\
\hline Wo & 47.00 & 47.58 & 47.24 & 47.23 & 47.67 & 47.87 & 48.38 & 43.20 \\
\hline En & 44.36 & 47.08 & 43.76 & 46.37 & 46.25 & 45.41 & 41.54 & 42.56 \\
\hline $\mathrm{Fe}$ & 8.64 & 5.34 & 9.00 & 6.40 & 6.08 & 6.72 & 10.08 & 14.23 \\
\hline Mg\# & 82.40 & 87.78 & 81.89 & 86.42 & 86.29 & 84.85 & 76.00 & 75.00 \\
\hline
\end{tabular}

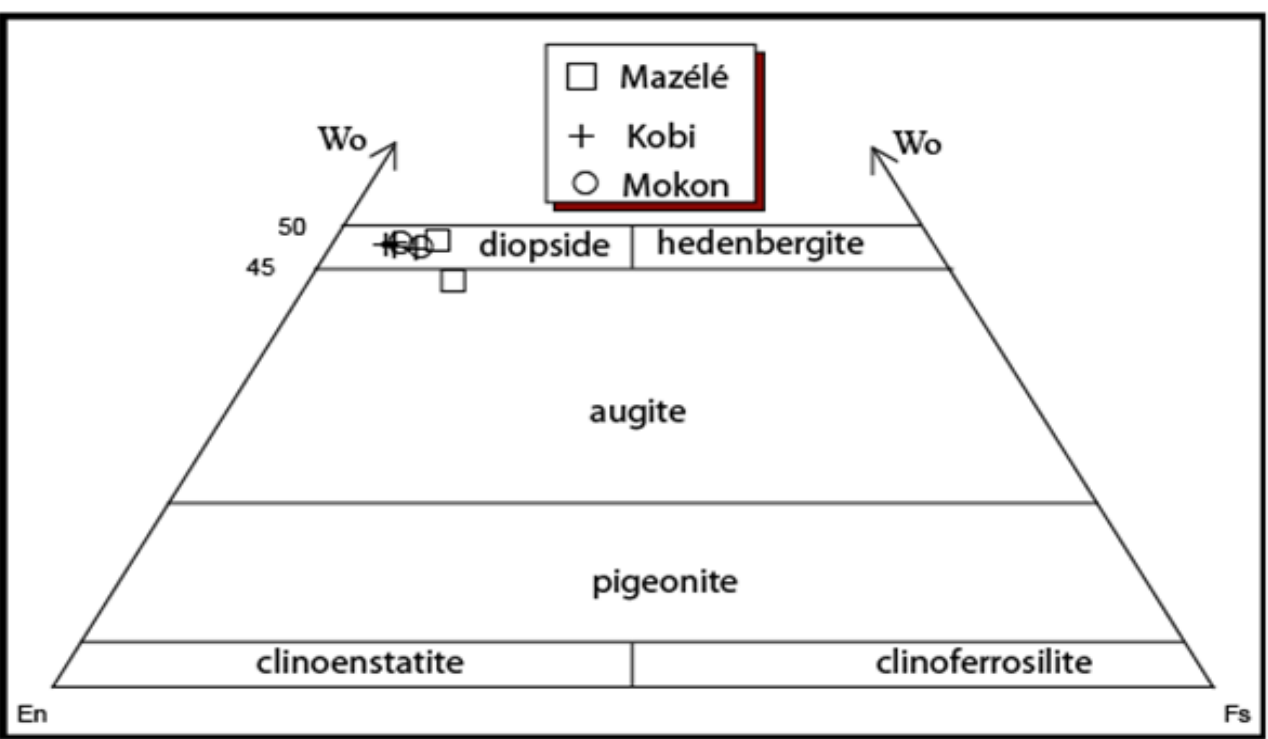

Fig. 4: Compositions of Analyzed Clinopyroxene Crystals of Host Peridotite Basaltic Lavas in Wo-En-Fs Triangle (After Morimoto Et Al. 1988). 


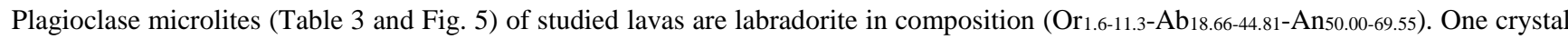
has nearly bytownite composition $\left(\mathrm{Or}_{0.67}-\mathrm{Ab}_{29.78}-\mathrm{An}_{69.55}\right)$. FeOt contents of plagioclase microlites are between 0.8 and $1.4 \mathrm{wt} \%$.

Oxides crystals of studied lavas (Table 4) are Ti-magnetite in composition $\left(\mathrm{TiO}_{2}:\right.$ 20.6-26.3 wt \% and $\mathrm{FeOt}: 64.5-68.6$ vol \%). $\mathrm{Al}_{2} \mathrm{O}_{3}$ (1.6-4.9 wt \%), $\mathrm{Cr}_{2} \mathrm{O}_{3}(0.1-2.7$ wt \%) and $\mathrm{MgO}$ (3.4-5.6 wt \%) show little variations and correspond to Usp contents between 61.5 and $64.5 \mathrm{wt} \%$. One crystal is peculiar with a chemical composition intermediate with those of spinel, with $9.0 \mathrm{wt} \% \mathrm{Al}_{2} \mathrm{O}_{3}$ and $7.1 \mathrm{wt} \%$ $\mathrm{Cr}_{2} \mathrm{O}_{3}$ for Usp content close to $2 \mathrm{wt} \%$.

Table 3: Microprobe Analyses and Structural Formulae of Plagioclase Crystals of Host Peridotites Basaltic Lavas

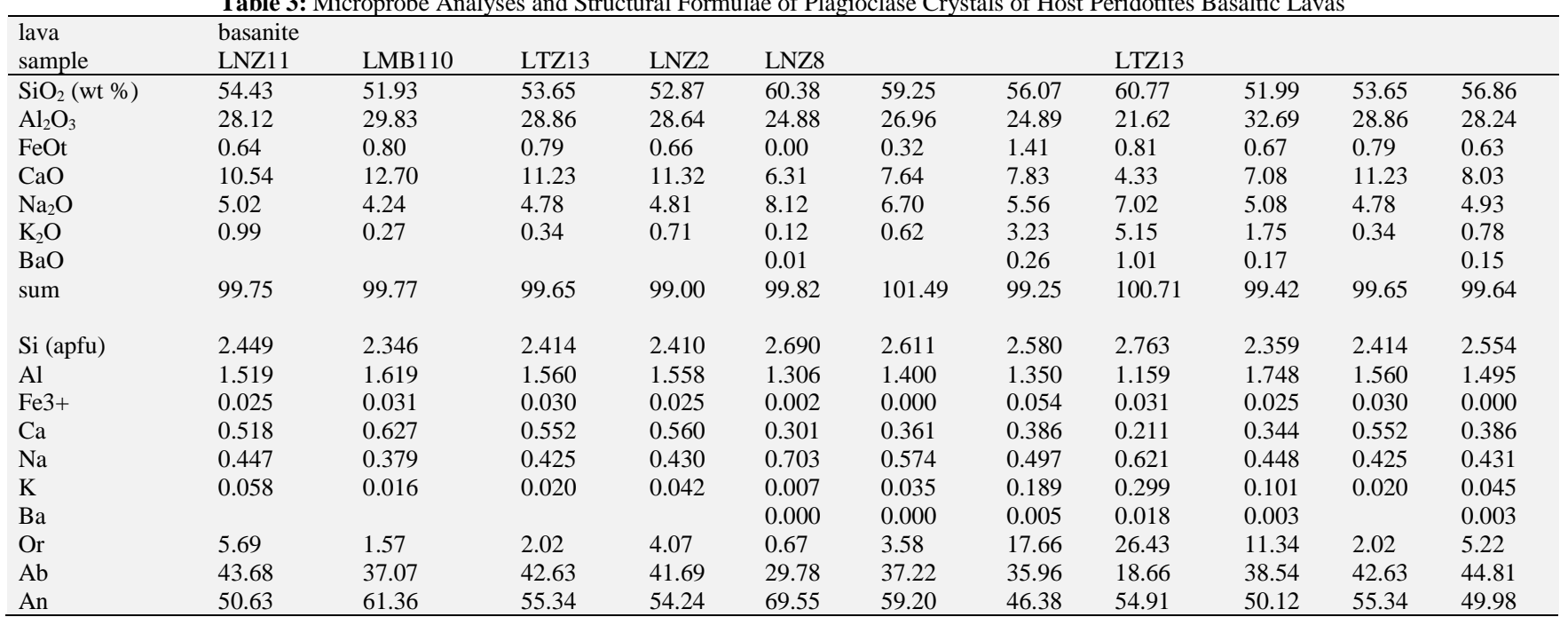

Table 4: Microprobe Analyses and Structural Formulae of Ti-Magnetite Crystals of Host Peridotites Basaltic Lavas

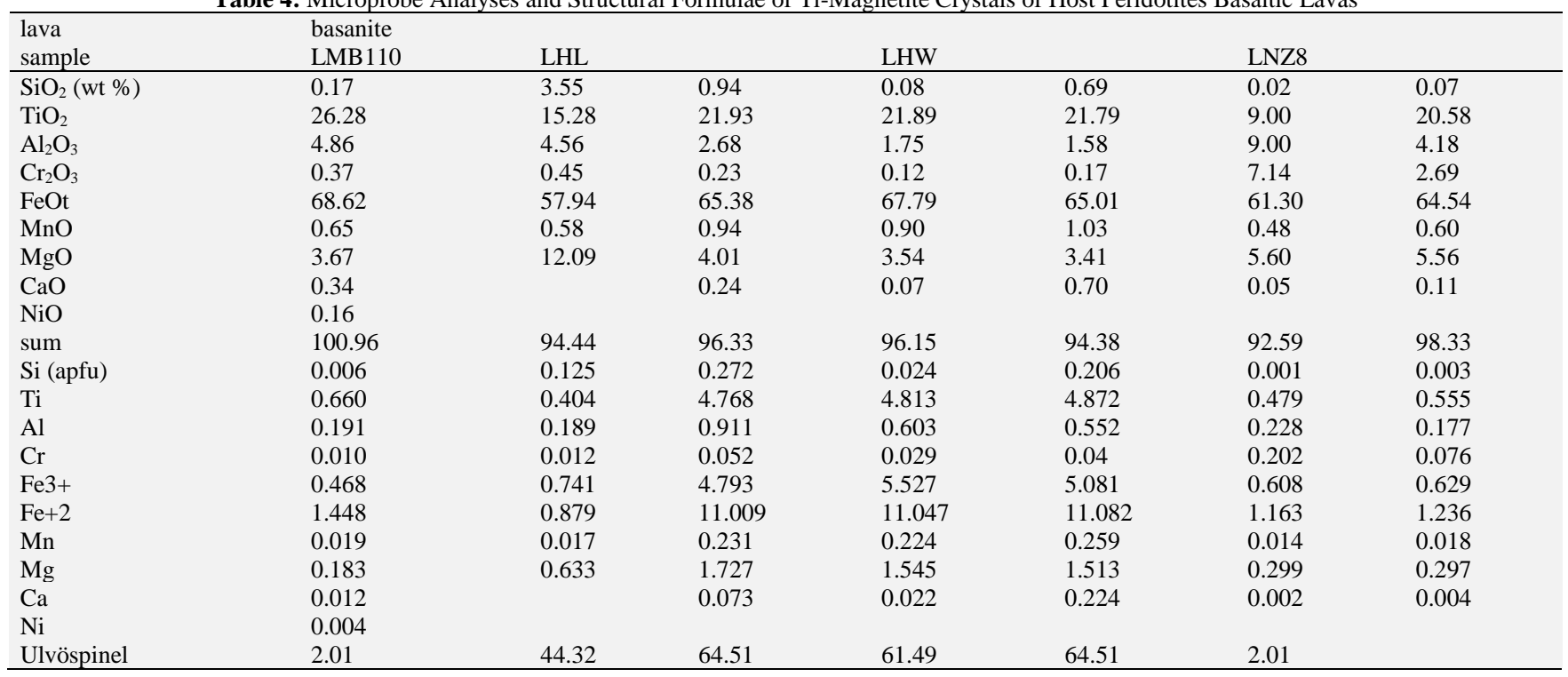

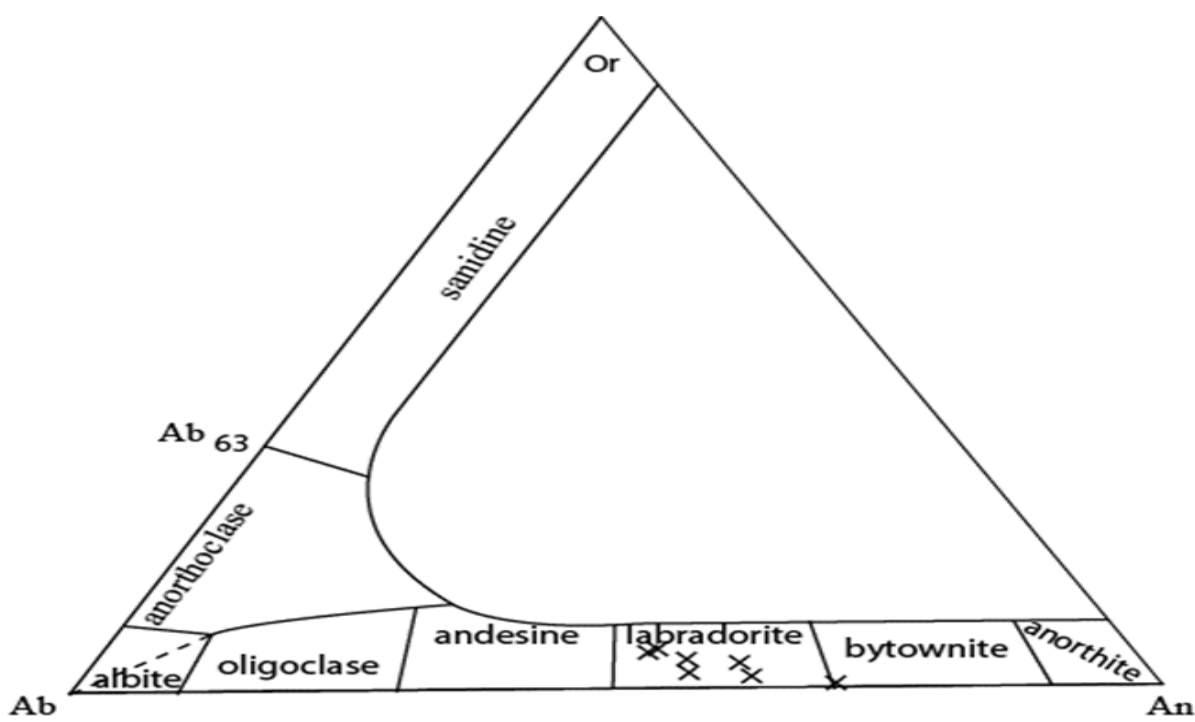

Fig. 5: Plagioclase Microlites Composition of Host Peridotite Basaltic Lavas in Or-Ab-An Triangle. 


\subsection{Geochemistry}

Representative host peridotite basaltic lavas (Table 5) of northern Ngaoundéré exhibit the features of under saturated basanite lavas composition (Fig. 6) according to $\mathrm{SiO}_{2}$ content less than $45 \mathrm{wt} \%$, normative olivine of 16.2-25\% and normative nepheline more than $10 \%$ (10.3-13.9 \%) (Le Maitre 2002). $\mathrm{TiO}_{2}\left(2.7-3.9\right.$ wt \%) and alkali $\left(\mathrm{Na}_{2} \mathrm{O}+\mathrm{K}_{2} \mathrm{O}\right)$ contents $(4.7$ to $6.0 \mathrm{wt} \%)$ are typically high. $\mathrm{Mg \#}$ varies between 49.7 and $68.5 \%$. Ni (123.0-402.7 ppm) and $\mathrm{Cr}(65-510.6 \mathrm{ppm})$ contents vary wildly while Co (43.9-59.7 ppm) and V (188-257 $\mathrm{ppm})$ contents are relatively constant. Rb contents (38-49 ppm) are low and $\mathrm{Sr}(758.9-1127.4 \mathrm{ppm})$ and $\mathrm{Ba}(538.0-795.0 \mathrm{ppm})$ are high. $\mathrm{Nb}$ (73-107 ppm), Ta (3.5-5.8 ppm), Hf (5.5-7.9 ppm) and Th (7.4-10.2 ppm) contents are low. Y (22.5-26.8 ppm) contents are constant. $\mathrm{Zr} / \mathrm{Nb}(41.2-47.7)$ and $\mathrm{Nb} / \mathrm{Ta}(14.3-19.6)$ ratios are relatively constant. Y/Nb ratios (0.24-0.32) are low. REE patterns (Fig. 7) show regular decreased normalized values from LREE to HREE and very high LREE ratios (up to 100 times the mantle values). (Ce/Yb)n ratios (14.2-20.3) are high. Regular decreased values are also shown by spider diagram (Fig. 8) from high incompatible to compatible elements. Positive anomalies are observed in $\mathrm{Nb}$, Ta and $\mathrm{Zr}$ and negative anomalies are observed in $\mathrm{K}, \mathrm{P}$ and $\mathrm{Ti}$.

\begin{tabular}{|c|c|c|c|c|c|}
\hline $\begin{array}{l}\text { locality } \\
\text { lava }\end{array}$ & $\begin{array}{l}\text { Kobi } \\
\text { basanite }\end{array}$ & $\begin{array}{l}\text { Kobi } \\
\text { basanite }\end{array}$ & $\begin{array}{l}\text { Béka } \\
\text { basanite }\end{array}$ & $\begin{array}{l}\text { Béka } \\
\text { basanite }\end{array}$ & $\begin{array}{l}\text { Mazélé } \\
\text { basanite }\end{array}$ \\
\hline sample & LNZ8 & LNZ2 & LNJ9 & LNJ36 & LTZ13 \\
\hline $\mathrm{SiO}_{2}$ (wt \%) & 43.75 & 42.48 & 42.26 & 42.29 & 43.26 \\
\hline $\mathrm{TiO}_{2}$ & 3.12 & 3.07 & 3.90 & 3.45 & 2.68 \\
\hline $\mathrm{Al}_{2} \mathrm{O}_{3}$ & 12.96 & 12.31 & 13.28 & 12.79 & 12.26 \\
\hline $\mathrm{Fe}_{2} \mathrm{O}_{3}$ & 12.19 & 12.10 & 14.47 & 13.54 & 11.49 \\
\hline $\mathrm{MnO}$ & 0.19 & 0.18 & 0.20 & 0.20 & 0.17 \\
\hline $\mathrm{MgO}$ & 12.17 & 12.33 & 8.03 & 9.86 & 14.02 \\
\hline $\mathrm{CaO}$ & 9.42 & 9.54 & 9.58 & 9.16 & 9.95 \\
\hline $\mathrm{Na}_{2} \mathrm{O}$ & 3.52 & 3.13 & 3.63 & 3.57 & 3.20 \\
\hline $\mathrm{K}_{2} \mathrm{O}$ & 1.75 & 1.60 & 2.36 & 2.21 & 1.48 \\
\hline $\mathrm{P}_{2} \mathrm{O}_{5}$ & 0.94 & 0.90 & 0.94 & 0.94 & 0.64 \\
\hline LOI & & 1.70 & 0.80 & 1.4 & 0.20 \\
\hline sum & 100 & 99.34 & 99.49 & 99.44 & 99.55 \\
\hline $\mathrm{Fe}_{2} \mathrm{O}_{3} / \mathrm{FeO}$ & 0.15 & 0.15 & 0.15 & 0.15 & 0.15 \\
\hline \multicolumn{6}{|l|}{ CIPW Norm } \\
\hline Orthoclase & 10.32 & 9.48 & 13.95 & 13.06 & 8.75 \\
\hline Albite & 8.28 & 7.40 & 5.03 & 5.50 & 4.58 \\
\hline Anorthite & 14.41 & 14.79 & 12.97 & 12.35 & 14.72 \\
\hline Nepheline & 11.63 & 10.35 & 13.91 & 13.38 & 12.18 \\
\hline Diopside & 21.07 & 21.43 & 23.22 & 21.87 & 24.41 \\
\hline Olivine & 23.02 & 23.14 & 16.22 & 19.60 & 24.95 \\
\hline Magnétite & 2.10 & 2.09 & 2.49 & 2.33 & 1.98 \\
\hline Ilmenite & 5.93 & 5.82 & 7.41 & 6.55 & 5.09 \\
\hline Apatite & 2.17 & 2.08 & 2.18 & 2.18 & 1.48 \\
\hline $\mathrm{Mg} \#$ & 64.02 & 64.49 & 49.73 & 56.48 & 68.50 \\
\hline $\mathrm{Be}(\mathrm{ppm})$ & 1.9 & 2.0 & 6.0 & 2.0 & 2.0 \\
\hline $\mathrm{Rb}$ & 49 & 43 & 49 & 40 & 38 \\
\hline $\mathrm{Sr}$ & 930 & 1034 & 1127 & 1193 & 759 \\
\hline Cs & & 0.52 & & & 0.40 \\
\hline $\mathrm{Ba}$ & 539 & 570 & 721 & 795 & 538 \\
\hline V & 188 & 203 & 257 & 226 & 220 \\
\hline $\mathrm{Cr}$ & 452.1 & 510.6 & 86.9 & 150.2 & 65.0 \\
\hline Co & 48.8 & 53.9 & 43.9 & 47.9 & 59.7 \\
\hline $\mathrm{Ni}$ & 345.1 & 402.7 & 123.0 & 207.0 & 382.8 \\
\hline $\mathrm{Cu}$ & & 43 & & & 38 \\
\hline $\mathrm{Sc}$ & 18.27 & 19.45 & 19 & 17 & \\
\hline Y & 25.4 & 26.8 & 25.9 & 26.3 & 22.5 \\
\hline $\mathrm{Zr}$ & 324 & 340 & 326 & 338 & 237 \\
\hline
\end{tabular}

\begin{tabular}{|c|c|c|c|c|c|}
\hline $\mathrm{Hf}$ & 7.0 & 7.1 & 7.9 & 7.9 & 5.5 \\
\hline $\mathrm{Ta}$ & 5.78 & 5.72 & 5.20 & 5.70 & 3.70 \\
\hline Th & 7.90 & 8.16 & 9.20 & 10.20 & 7.40 \\
\hline $\mathrm{Ga}$ & 18.0 & 18.9 & 20.2 & 19.8 & \\
\hline $\mathrm{Sn}$ & 3 & 2 & 2 & 2 & \\
\hline W & 0.9 & 1.2 & 1.2 & 1.2 & \\
\hline $\mathrm{Nb}$ & 83 & 83 & 97 & 107 & 73 \\
\hline $\mathrm{Zn}$ & 109 & 120 & 113 & 116 & 73 \\
\hline $\mathrm{La}$ & 61.6 & 63.2 & 75.4 & 83.3 & 54.5 \\
\hline $\operatorname{Pr}$ & 13.5 & 14.1 & 15.6 & 16.3 & 11.1 \\
\hline $\mathrm{Nd}$ & 52 & 55 & 58 & 63 & 42 \\
\hline $\mathrm{Sm}$ & 10.1 & 10.6 & 10.9 & 11.4 & 8.0 \\
\hline $\mathrm{Eu}$ & 3.1 & 3.3 & 3.2 & 3.4 & 2.5 \\
\hline $\mathrm{Gd}$ & 8.02 & 8.40 & 9.26 & 9.36 & 7.20 \\
\hline $\mathrm{Tb}$ & 1.077 & 1.130 & 1.210 & 1.210 & 0.980 \\
\hline Dy & 5.73 & 5.98 & 5.93 & 6.06 & 5.04 \\
\hline Ho & 1.01 & 1.06 & 1.07 & 1.05 & 0.91 \\
\hline $\mathrm{Tm}$ & 0.30 & 0.30 & 0.32 & 0.29 & 0.28 \\
\hline
\end{tabular}




\begin{tabular}{llllll}
\hline $\mathrm{Yb}$ & 1.76 & 1.84 & 2.00 & 2.04 & 1.80 \\
$\mathrm{Lu}$ & 0.25 & 0.27 & 0.23 & 0.28 & 0.24 \\
\hline
\end{tabular}

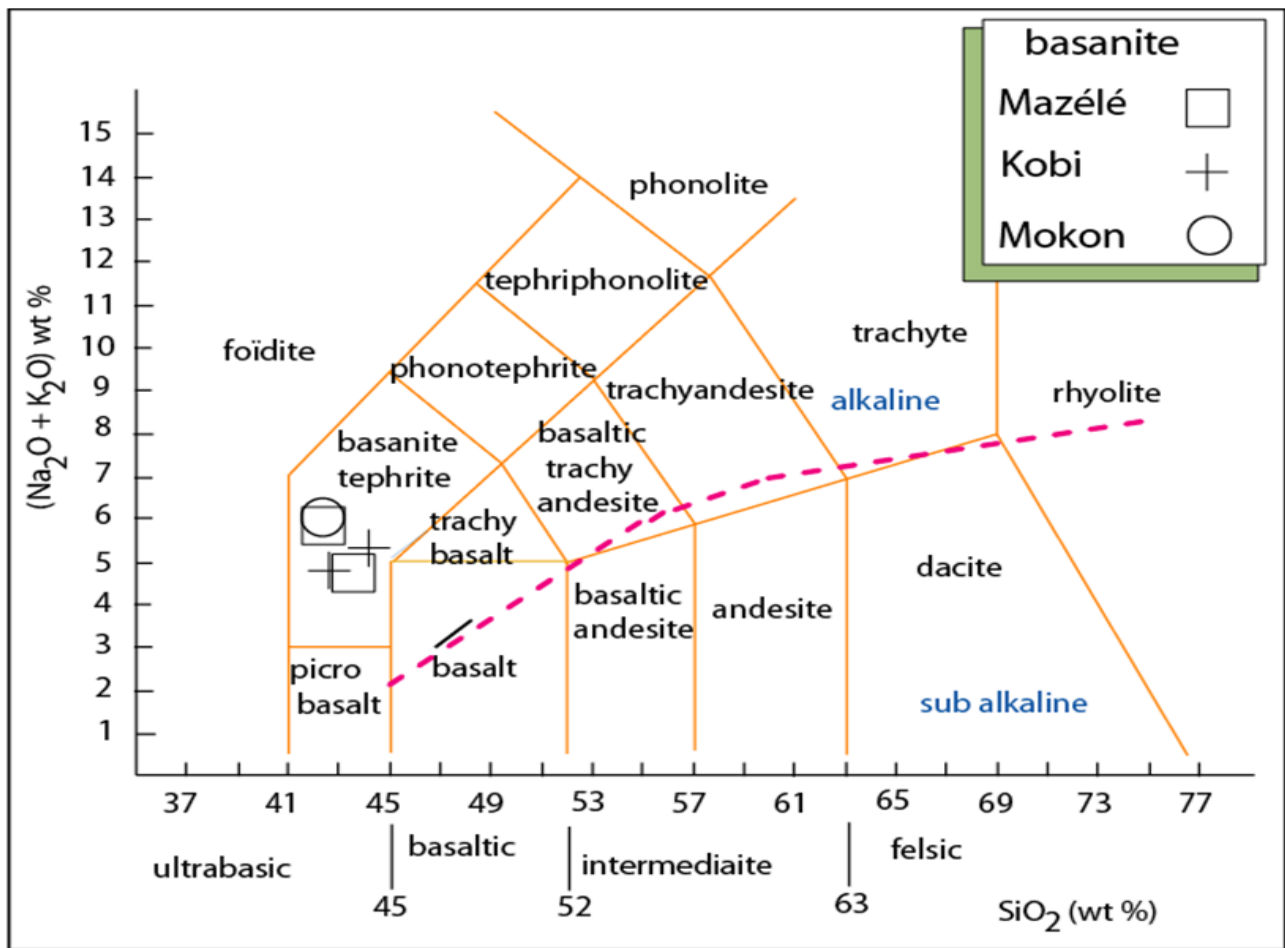

Fig. 6: TAS Diagram (After Le Maitre 2002) of Upper Lava Series Northern Ngaoundéré Located in the Basanite Field. Dashed Line Separating Alkaline and Sub Alkaline Fields (after Miyashiro 1978).

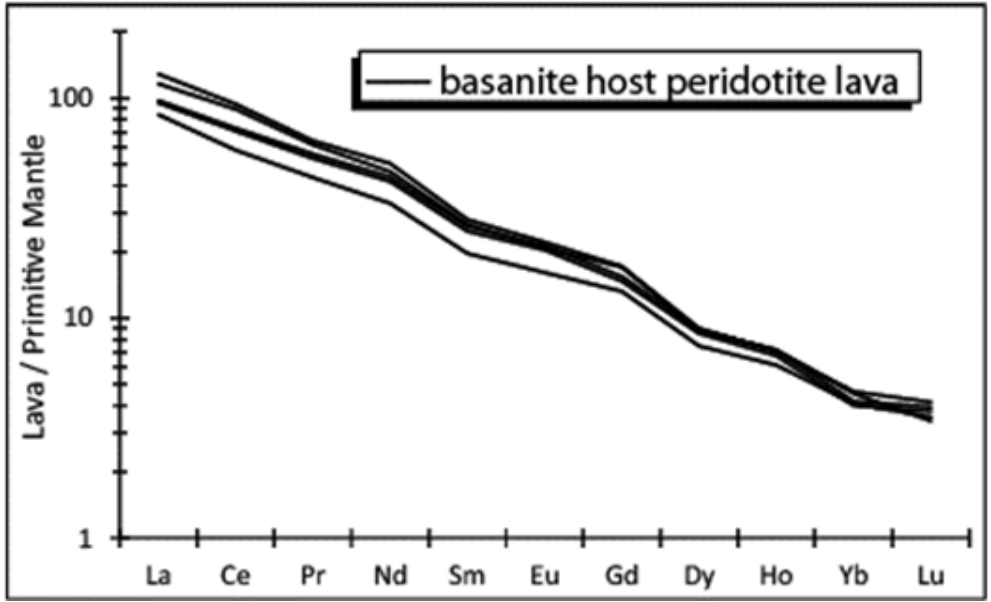

Fig. 7: Normalized (After Mcdonough \& Sun 1995) REE of Peridotite Host Basanite Lavas of Northern Ngaoundéré.

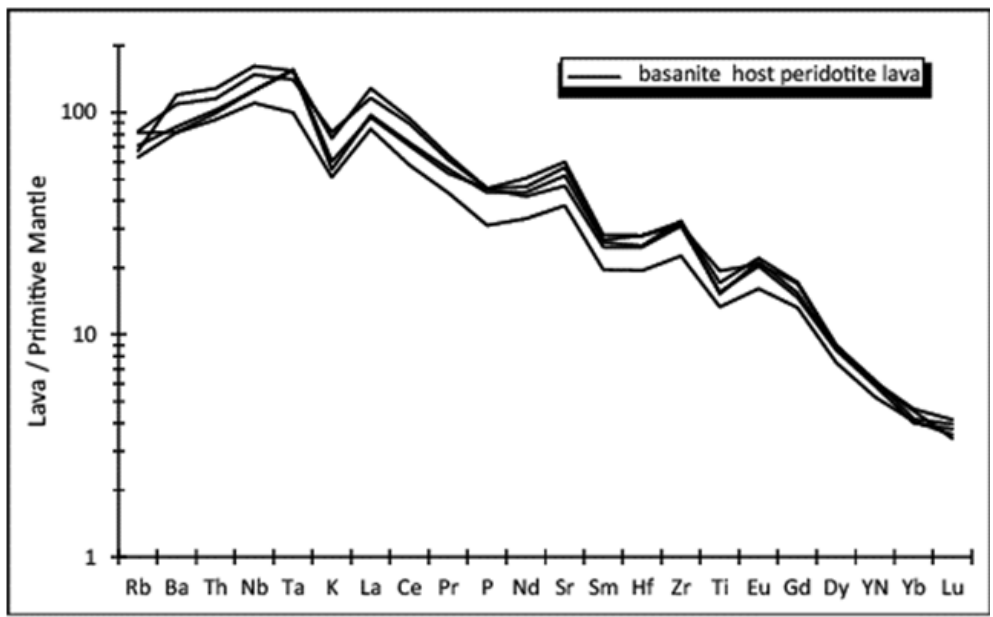

Fig. 8: Multielements Spiderdiagram (Normalization after Mcdonough \& Sun 1995) of Peridotite Host Basanite Lavas of Northern Ngaoundéré. 


\section{Discussion}

Representative compositions of host peridotite basanite lavas of northern Ngaoundéré exhibit the characteristic features of undersaturated alkaline basaltic lavas worldwide (Le Maitre 2002). $\mathrm{SiO}_{2}$ contents are low, alkali and $\mathrm{TiO}_{2}$ contents are high. High normative olivine and nepheline lead to deep under saturated alkali lava series. Studied basanite show some rather evolved characters (Ni: 123.0-402.7 ppm; Cr: 65-510.6 ppm and Co: 43.9-59.7 ppm) probably due to early olivine, oxides, clinopyroxene and late plagioclase microlites crystallization. Basanite host peridotite lava with high Mg\# (68.5) closed to mantle materials (Wilkinson \& Le Maitre 1987) but with low Cr, Co and relatively low Ni contents might have undergone a magma process other than fractional crystallization. High $(\mathrm{Ce} / \mathrm{Yb}) \mathrm{n}(14.2-20.3)$ and $(\mathrm{La} / \mathrm{Yb}) \mathrm{n}$ (20.6-27.8) ratios of studied lava are consisting with a low partial melting rate of a deep mantle source as suggested by the low values of heavy REE (Fig. 7), probably not far from 2 to $3 \%$ partial melting (Nkouandou et al. 2008 and 2010) of the Adamawa basaltic mantle source. Low HREE may also suggest the presence of garnet phase in the host basanite mantle source i.e. at more than 80 $\mathrm{km}$ and between 2 to $3.5 \mathrm{Gpa}$ (Stern et al. 1990) or 3.6 to $4.2 \mathrm{Gpa}$ obtained from the Scarrow \& Cox (1995) formula. Thus, northern Ngaoundéré basanite have sampled mantle peridotite at different pressures and different depths. The assumption of the presence of the garnet phase in the basanite mantle source is sustained by positive $\Delta \mathrm{Nb}(0.1-0.3)$ of basanite lavas (Fitton et al. 1997) and their high (Dy/Yb)n ratios (Blundy et al. 1998). Spiderdiagram of host peridotite lavas (Fig. 8) show negative anomaly in K, P and Ti. K anomaly can be considered as the characteristic feature of the peridotite host lavas mantle source as have been suggested by Nkouandou et al. (2010) for whole Adamawa plateau Mio-Pliocene basaltic lavas. P and T anomalies are ascribed to the early crystallization of apatite and Ti-oxides phases in those basanite. Crustal contamination is not conceivable as the presence of ultrabasic mantle fragments of centimeters size in those lavas strongly suggest the rapid ascent of the host peridotites basanite from the magma chamber in their way to the surface, trough Pan African cracks of northern Ngaoundéré (Dumont 1987, Moreau et al. 1987, Poudjom Djomani et al. 1997, Fagny et al. 2016). High contents of $\mathrm{Nb}$ and $\mathrm{Ta}$ are in favor of the non-contamination of studied lava by the crustal materials.

\section{Conclusion}

Northern Ngaoundéré basaltic lavas are Pliocene-Quaternary upper black alkaline lava series of basanite in composition. Those lavas have sampled numerous fragments of mantle peridotite during their rapid ascent from the magma chamber in their way to the surface, trough Pan African cracks of the area, at different pressures and depths. They exhibit the little evolved characters after an early crystallization of olivine, clinopyroxene, oxides and late crystallization of plagioclase microlites. Basanite host peridotite lavas of northern Ngaoundéré are not contaminated by crustal materials. They are the results of the low partial melting rate of the garnet mantle source, located at more than $80 \mathrm{~km}$.

\section{Acknowledgments}

Authors greatly thank the "Agence Universitaire de la Francophonie (AUF)" through the BAGL (Bureau Afrique Centrale et des Grands Lacs) for financial support of "Le Projet de soutien aux équipes de recherche 2012/2013_No 51110SU201" for supplement analyses.

\section{References}

[1] Blundy JD, Robinson JAC \& Wood BJ (1998) Heavy REE are compatible in clinopyroxene on the spinel lherzolite solidus. Earth Planet Science Letter 160 (3), 493-504. https://doi.org/10.1016/S0012-821X(98)00106-X.

[2] Carignan J, Hild P, Mévelle G, Morel J \& Yeghicheyan D (2001) Routine analyses of trace elements in geological samples using flow injection and low pressure on-line liquid chromatography couple to ICP-MS: a study of geochemical reference materials BR, DR-N, UB-N, AN-G and GH. The Journal of Geostandards and Geoanalysis 25 (2-3), 187-198. https://doi.org/10.1111/j.1751-908X.2001.tb00595.x.

[3] Cornacchia M \& Dars R (1983) Un trait structural majeur dc continent africain. Les linéaments centrafricains du Cameroun au Golfe d'Aden. Bulletin de la Société Géologique de France 25, 101-109. https://doi.org/10.2113/gssgfbull.S7-XXV.1.101.

[4] Dorbath C, Dorbath L, Fairhead JD \& Stuart W (1986) A teleseismic delay time study across the Central African Shear Zone in the Adamawa region of Cameroon, West Africa. Geophysical Journal of the Royal Astronomical Society 86, 751-766. https://doi.org/10.1111/j.1365246X.1986.tb00658.x.

[5] Dumont JF (1987) Identification par télédétection de l'accident de la Sanaga (Cameroun). Sa position dans le contexte des grands accidents d'Afrique Centrale et de la limite nord du craton congolais. Géodynamique 2 (1), 55-68. http://horizon.documentation.ird.fr/exldoc/pleins_textes/cahiers/geodyn/23608.pdf

[6] Fagny AM, Nkouandou OF, Déruelle B \& Ngounouno I (2012) Revised petrology and new chronological data on the peralkaline felsic lavas of Ngaoundéré volcanism (Adamawa plateau. Cameroon. Central Africa): evidence of open-system magmatic processes Analele Stiintifice ale Universitatii “Al. I. Cuza” din Iasi. Seria Geologie 58 (2), 5-22. http://geology.uaic.ro/auig/

[7] Fagny AM, Nkouandou OF, Temdjim R, Bardintzeff JM, Guillou H, Stumbea D \& Boutaleb A 2016 New K-Ar ages of Tchabal Mbabo alkaline volcano massif. Cameroon volcanic line and Adamawa plateau (central Africa). International Journal of Advanced Geosciences 4 (2), 62-71. https://doi.org/10.14419/ijag.v4i2.6516.

[8] Fitton JG, Saunders AD, Norry MJ, Hardarson BS \& Taylor RN (1997) Thermal and chemical structure of the Iceland plume. Earth and Planetary Science Letters 153 (3-4), 197-208. https://doi.org/10.1016/S0012-821X(97)00170-2.

[9] Guiraud R \& Maurin JC (1992) Early Cretaceous rifts of Western and Central Africa: an overview. Tectonophysics 213, 153- 168. https://doi.org/10.1016/0040-1951(92)90256-6.

[10] Le Maitre RW (2002) Igneous Rocks - A Classification and Glossary of Terms. Recommendations of the IUGS Sub-Commission on the Systematics of Igneous Rocks. 2nd edition. Cambridge University Press, Cambridge. https://doi.org/10.1017/CBO9780511535581.

[11] McDonough WF \& Sun SS (1995) The composition of the Earth. Chemical Geology 120, 223-253. https://doi.org/10.1016/0009-2541(94)00140-4

[12] Miyashiro A. (1978) Nature of alkalic volcanic rock series. Contributions to Mineralogy and Petrology 66, 91-104. 0010-7999/78/0066/0091. https://doi.org/10.1007/BF00376089.

[13] Moreau CJ, Regnoult M, Déruelle B \& Robineau B (1987) A new tectonic model for the Cameroon Line. Central Africa. Tectonophysics 139, 317 334. https://doi.org/10.1016/0040-1951(87)90206-X.

[14] Morimoto N, Fabries J, Ferguson AK, Ginzburg IV, Ross M, Seifert FAJ, Zussman J, Aoki K \& Gottardi G (1988) Nomenclature of pyroxenes. Mineralogical Magazine 52, 535-550. https://doi.org/10.1180/minmag.1988.052.367.15. 
[15] Njombie MPW, Temdjim R \& Foley SF (2018) Petrology of spinel lherzolite xenoliths from Youkou volcano, Adamawa Massif, Cameroon Volcanic Line: mineralogical and geochemical fingerprints of sub-rift mantle processes. Contributions to Mineralogy and Petrology 173 (13), 1-20. https://doi.org/10.1007/s00410-018-1438-5.

[16] Nkouandou OF, Ngounouno I, Déruelle B, Ohnenstetter D, Montigny R \& Demaiffe D (2008) Petrology of the Mio-Pliocene Volcanism to the North and East of Ngaoundéré (Adamawa-Cameroon). Comptes Rendus Geoscience 340, 27-38. https://doi.org/10.1016/j.crte.2007.10.012.

[17] Nkouandou OF, Bardintzeff JM \& Fagny AM (2015) Sub-continental lithospheric mantle structure beneath the Adamawa plateau inferred from the petrology of ultramafic xenoliths from Ngaoundéré (Adamawa plateau. Cameroon. Central Africa). Journal of African Earth Sciences 111, 26-40. https://doi.org/10.1016/j.jafrearsci.2015.07.004.

[18] Nkouandou OF, Ngounouno I \& Déruelle B (2010) Geochemistry of recent basaltic lavas from the north and east of Ngaoundéré zones (Cameroon, Adamawa Plateau, Central Africa): petrogenesis and the nature of the source. International Journal of Biological and Chemical Science 4 (4), 9841003. https://doi.org/10.4314/ijbcs.v10i4.38.

[19] Nkouandou OF, Sahabo A, Fagny AM, Bardintzeff JM, Atour MM, Tizi A \& Abondou T (2016) Petrography and geochemical features of bimodal volcanism from Saltaka (Adamawa-Plateau. Cameroon. Central Africa). Sciences, Technologies et Développement, Douala 18, 1-14. http://www.univ-Douala.com/STD/.

[20] Nkouandou OF \& Temjim R (2011) Petrology of spinel lherzolite xenoliths and host basaltic lava from Ngao Voglar volcano, Adamawa Massif (Cameroon Volcanic Line, West Africa): equilibrium conditions and mantle characteristics. Journal of Geosciences 56, $375-387$. https://doi.org/10.3190/jgeosci.108.

[21] Nnange JM, Ngako V, Fairhead JD \& Ebinger CJ (2000) Depths to density discontinuities beneath the Adamawa Plateau region, Central Africa, from spectral analyses of new and existing gravity data. Journal of African Earth Sciences 30 (4), 887-901. https://doi.org/10.1016/S08995362(00)00058-0.

[22] Nono A, Déruelle B, Demaiffe D \& Kambou R (1994) Tchabal Nganha volcano in Adamawa (Cameroon): petrology of a continental alkaline lava series. Journal of Volcanology Geothermal Research 60, 147-178. https://doi.org/10.1016/0377-0273(94)90066-3.

[23] Pouchou JL \& Pichoir F (1991) Quantitative analysis of homogeneous or stratified microvolumes applying the model "PAP". In: Electron probe quantification (Heinrich KFJ and Newbury DE, Eds.), Plenum Press, New York, USA, 31-75. https://doi.org/10.1007/978-1-4899-2617-3_4.

[24] Poudjom Djomani YH, Diament M \& Albouy Y (1992) Mechanical behaviour of the lithosphere beneath the Adamawa uplift (Cameroon, West Africa) based on gravity data. Journal of Africa Earth Science 15, 81-90. https://doi.org/10.1016/0899-5362(92)90009-2.

[25] Poudjom Djomani YH, Diament M \& Wilson M (1997) Lithospheric structure across the Adamawa plateau (Cameroon) from gravity studies. Tectonophysics 273 (3-4), 317-328. https://doi.org/10.1016/S0040-1951(96)00280-6.

[26] Scarrow JH \& Cox KG (1995) Basalts generated by decompressive adiabatic melting of a mantle plume: a case study from the Isle of Skye, NW Scotland. Journal of Petrology 36, 3-22. https://doi.org/10.1093/petrology/36.1.3.

[27] Stern CK, Frey FA, Futa K, Zartman RE, Peng Z \& Kyser TK (1990) Trace element and Sr. Nd. Pb. O isotopic composition of Pliocene and Quaternary alkali basalts of the Patagonian Plateau lava of southermost South America. Contribution to Mineralogy and Petrology 104, 294-308. https://doi.org/10.1007/BF00321486.

[28] Tchameni R, Pouclet A, Penaye J, Ganwa AA \& Toteu SF (2006) Petrography and geochemistry of the Ngaoundéré Pan-African granitoids in central North Cameroon: implications for their sources and geological setting. Journal of African Earth Sciences 44, 511-529. https://doi.org/10.1016/j.jafrearsci.2005.11.017.

[29] Temdjim R, Njilah IK, Kamgang P \& Nkoumbou C (2004) Données nouvelles sur les laves felsiques de Ngaoundéré (Adamaoua. ligne du Cameroun): chronologie $\mathrm{K}-\mathrm{Ar}$ et pétrologie. African Journal of Science and Technology Sciences and Engineering 5 (2), 113-123. https://doi.org/10.4314/ajst.v5i2.15338.

[30] Tiabou AF, Temdjim R, Ngwa CN, Che VB \& Mebara FXO (2015) Polymagmatic Processes at Monogenetic Volcanoes: Insights from Baossi Monogenetic Lava Flows, Adamawa Plateau, Cameroon Volcanic Line. Journal of Geography and Geology 7 (2), 56-69. https://doi.org/10.5539/jgg.v7n2P56.

[31] Wilkinson JFG \& Le Maitre RW (1987) Upper mantle amphiboles and micas and $\mathrm{TiO}_{2}, \mathrm{~K}_{2} \mathrm{O}$ and $\mathrm{P}_{2} \mathrm{O}_{5}$ abundances and $100 \mathrm{Mg} /\left(\mathrm{Mg}+\mathrm{Fe}{ }^{2+}\right)$ ratios of common basalts and andesites: implications for modal mantle metasomatism and undepleted mantle compositions. Journal of Petrology 28 (1), 37 73. https://doi.org/10.1093/petrology/28.1.37. 